\title{
放射光を用いたマイクロコネクタの開発
}

\author{
羽賀 剛 ${ }^{*}$, 奥山 浩*, 平田 嘉裕 ${ }^{*}$, 芳賀 孝吉*, 高田 博史 ${ }^{*}$
}

\section{Development of Micro Connector Using Synchrotron Radiation}

Tsuyoshi HAGA* , Hiroshi OKUYAMA*, Yoshihiro HIRATA* , Koukichi HAGA* and Hiroshi TAKADA*

*住友電気工業株式会社播磨研究所（ $678-1205$ 兵庫県赤穂郡上郡町光都3-12-1）

*Harima Research Laboratories, Sumitomo Electric Industries, Ltd. (Harima Science Garden City, 3-12-1 Kohto, Kamigori-cho, Akoh-gun, Hyogo 678-1205)

\begin{abstract}
概要 マイクロマシンに搭載しマシン同士を連結するためのマイクロコネクタ（直径 $2.5 \mathrm{~mm}$, 厚さ $2 \mathrm{~mm}$ ）を開発した。 このマイクロコネクタは幅 $7 \mu \mathrm{m}$, 高さ $80 \mu \mathrm{m}$, 長さ $300 \mu \mathrm{m}$ の片持ち梁構造の端子を 24 本有し, 端子はシンクロトロン放射光の X線を用いたディープX線リソグラフイ技術と微細めっきを組み合わせて製作した。われわれは, 結晶子サイズを小さくし， 結晶子サイズや配向をめっき成長方向に揃えることで, Niめっき構造体のヤング率および勒性を高くし，端子製作に適用し た。マイクロコネクタの電気的特性を測定し，マイクロマシンからの要求仕様を満たすことを確認した。
\end{abstract}

\section{Abstract}

We developed micro connectors for chain-type micromachines those inspected the outer surface of tubes in the heat exchanger of power plants. The micromachines are linked to each other via the micro connectors. The diameter and thickness of the micro connector are $2.5 \mathrm{~mm}$ and $2 \mathrm{~mm}$, respectively. The electrical terminals (width $: 7 \mu \mathrm{m}$, hight $: 80 \mu \mathrm{m}$, length $: 300 \mu \mathrm{m}$ ) were designed to minimize the friction force during connection/disconnection and were fabricated using deep X-ray lithography and micro Ni electroplating. To obtain a desirable characteristic as a terminal spring, we developed $\mathrm{Ni}$ electroforming technique that realized the small grain size $(10 \mathrm{~nm})$ and the preferred orientation of the grain (111). Therefore, the Young's modulus and elastic limit of this Ni structure are very high $(250 \mathrm{MPa}$ and $1000 \mathrm{MPa}$, respectively). We confirmed the electrical tests of micro connectors and the automatic connection and disconnection between the micromachines.

Key Words: LIGA, Micromachine, Connector, Electroforming, Grain Size, Young's Modulus

\section{1. 緒 言}

マイクロマシンはその小さなサイズによる制限から 1 台 当たりの出力や機能に限界がある。このため, 多数のマイ クロマシンを集団で動かし，より大きな出力やより高度な 機能を取り出す多数分散型マイクロマシンシステムが提案 されている。

その例として, 通産省工業技術院のマイクロマシンプロ ジェクトの 1 つである「細管群外部検査用試作システム」 がある (Fig. 1 $)^{1121}$ 。これは, 発電施設の熱交換器のよう な林立する細管の外部損傷の有無を検査するためのマイク ロマシンシステムである。狭い細管間を通過可能なように 小型で，かつ，ある程度大きな検査領域を確保し，多くの 機能（探傷機能, 通信機能など）を満足することが要求さ れており，これら相反する要求を満足させるため，小さな マイクロマシンごとに必要最小限の機能を分散させ，作業 は多数のマイクロマシンを連結して行う。

マイクロコネクタはこれらマイクロマシンを機械的・電 気的に連結する機能を担っており，Fig. $2^{2} に$ 示すように

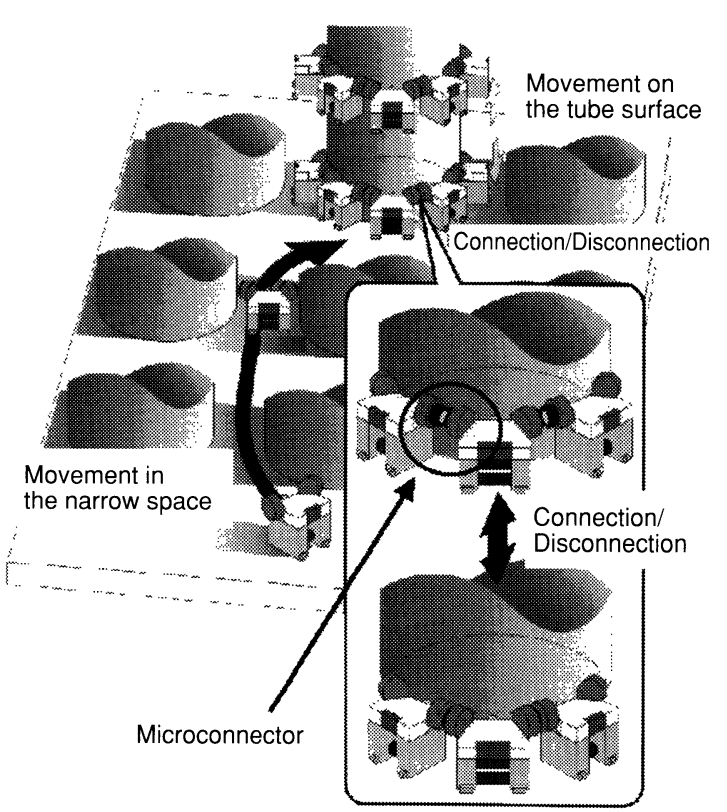

Fig.1 Schematic view of the system for inspection on the outer surface of tubes 


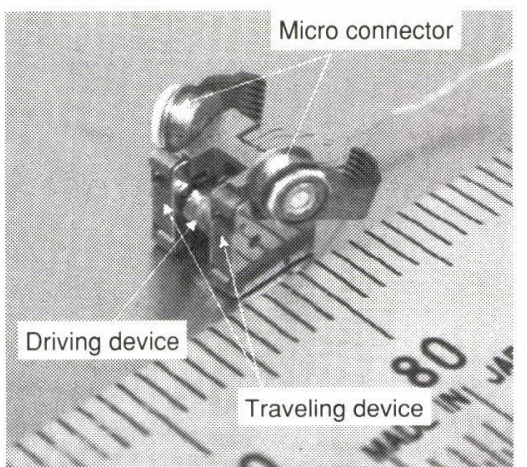

Fig.2 Prototype of component micromachine

マシンの上部両側に配置されている。マイクロマシン同士 の連結/分離は, 人の手の届かないところで行う必要があ ることから, マイクロコネクタは電磁アクチュエータによ る自動着脱機能を有している。また, きわめて小さな領域 に多数の電極端子を配置し, かつ確実な電気的な接触を確 保するため高精度に端子を製作する必要から，放射光のX 線を用いたリソグラフィ（Deep X-ray Lithography： DXL）技術を端子製作に適用することを試みだけ5)。本論 文では, めっきによる微細端子の製作を主に, マイクロコ ネクタの基本設計および製作プロセス, 電気的な特性の測 定結果について報告する。

\section{2. マイクロコネクタの設計}

マイクロコネクタの構造をFig. $3^{33.4} に$, 本マイクロマシ ンシステムからのマイクロコネクタの要求仕様をTable 1 に示す。マイクロコネクタの電極端子はアルミナ絶縁基板 上に製作し，アルミナ基板内の貫通電極を介して基板背面 Male-connector

Female-connector

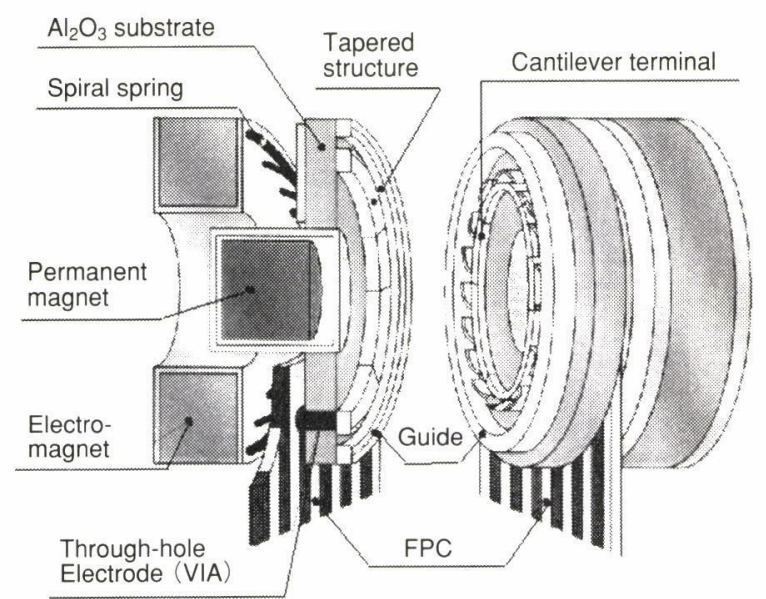

Fig.3 Schematic view of the microconnector

Table 1. Microconnector requirements

\begin{tabular}{l|c}
\hline Connection/Disconnection & $\begin{array}{c}\text { Automatic } \\
\text { (remote control) }\end{array}$ \\
Connectable Distance & $>500 \mu \mathrm{m}$ \\
Thickness & $<2 \mathrm{~mm}$ \\
Diameter & $<2.5 \mathrm{~mm}$ \\
Electric line & 7 \\
Current rating & $150 \mathrm{~mA} /$ line \\
Voltage rating & $60 \mathrm{~V}$ \\
Frequency range & $\mathrm{DC} \sim 1 \mathrm{MHz}$ \\
\hline
\end{tabular}

でFPC(Elexible Printed Cable)と接続している。この構成 を用いることで配線スペースを最小限にした。FPCと貫通 電極との接続は, FPC側に高さ $80 \mu \mathrm{m}$ 程度のバンプを設け 導電性接着剂を用いて接続している。

2.1 アライメントシステム(自動着脱システム)

マイクロマシン同士が連結する際にマシン間の位置ずれ がある程度大きくてもコネク夕側で吸収できることが求め られており, 自動着脱可能な裕度（ギャップばらつき，角 度ばらつき等に対する裕度）が大きいコネクタを製作する 必要があった。このため, コネクタの端子とテーパを有す るガイドを環状に配置することで, あらゆる方向からの挿 入に対応できるようにするとともに, 中心に永久磁石を置 くことでコネクタ同士の傾きを自動的に補正できる構造と している (Fig. 4)。コネクタの駆動力は電磁石によって 発生し, コネタタが近づくにつれて永久磁石同士の吸引力 が増し, 電磁石による駆動力の減少を補う。連結は永久磁 石の吸引力のみで保たれ, 連結中の電力消費はない。コネ クタの分離は電磁石を逆励磁することで中央の永久磁石を 分離し磁石の吸引力を弱め，ばねの反発力によってコネク 夕を外すことで複数個のコネクタを一括して着脱すること が可能になる。

\section{2 端子構造の設計}

微細な端子を製作する場合, その構造はできるだけ単純 なほうが好ましい。しかし，大気中に曝されているコネク 夕の電極端子は，たとえ表面が金でコーティングされてい ても端子の污染を防ぐことは困難であり ${ }^{6)}$, 端子接触には 単純な突き合わせではなく, 端子表面の污れを拭い去る効 果 (ワイピング効果) が期待できる構造が求められる。そ こで, マイクロコネクタには, 構造が単純な片持ち梁構造 の端子と固定端子を用い両者を差込む方式を採用した。ま た，コネクタ面あたりの端子密度を下げずに $150 \mathrm{~mA} /$ 線の 大電流通電を実現するため, 端子の高さ方向に接触面積を 稼ぐ構造とした。

コネクタの自動着脱を実現し駆動アクチュエータのサイ ズをできるだけ小さくするには，挿抜抵抗となる端子の接
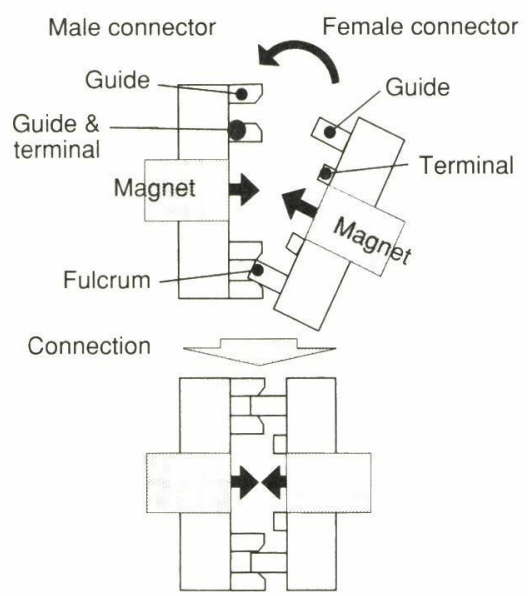

Fig.4 Principle of rectification force generation 
触圧力を低くする必要があった。微細な模擬端子を用いた 予備実験から，金一金接触において安定した接触電気抵抗 が得られる端子の接触荷重は $0.5 \mathrm{mN}$ 以上であり,この結果 よりマイクロコネクタ 1 端子の設計上の接触荷重を $0.5 \mathrm{mN}$ と決めた3!。安定した電気接触が得られる限界の接触荷重 值を選んだため, 接触荷重のばらつきによる接触不良の発 生を抑える必要から, 端子のばね定数に高い精度が必要で あった。また, 片持ち梁構造において曲げに対する発生荷 重は端子幅の 3 乗に比例するため, 端子幅には $\pm 0.5 \mu \mathrm{m}$ 以 下の寸法精度が必要となった。そこで, われわれはこの端 子の製作に高精度高アスペクト（高さ/幅）比微細構造体 製作が可能なDXL技術を採用した。DXL技術による端子 製作の詳細については次章で述べる。所望のばね特性を得 られる片持ち梁構造端子の寸法は, 有限要素法による解析 結果とDLX技術によって製作した模擬端子を用いた実測 結果を元に設計を行っだ)。

\section{3. 電極端子およびガイドの製作}

DXLはシンクロトロン放射光リングからの高輝度, 高 透過性 (短波長) で指向性良いX線の特徴を利用し, 高精 度に製作した等倍転写型X線マスクを用いて，高アスペク 卜比構造体を高精度加工する技術である7。先に述べたよ うに, 高い精度と高アスペクト比構造が要求されるマイク ロコネクタの電気端子はDXL技術を用いて製作した。ま た,コネクタガイド部もコネクタの位置決めや端子の保護 のため, 高い寸法精度と高アスペクト構造が要求されるの で，DXL技術を用いて端子とともに一括して製作した。 さらに，DXLによってできたレジスト構造体の間にめっ きを行い，その後レジストを除去することで金属構造体の 端子およびガイドを製作する (LIGA-like Process)。

\section{1 電気端子の製作方法}

片持ち梁構造の端子はLIGA-like Processと犠牲層プロ セスを組み合わせて製作した（Fig. 5 ）。このようにする

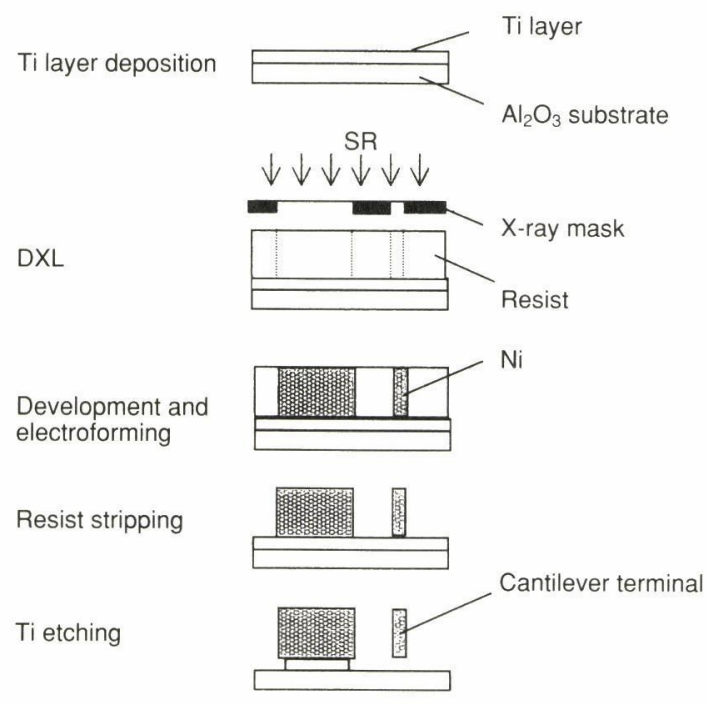

Fig.5 Flow of one-layer sacrificial process for cantilever terminals

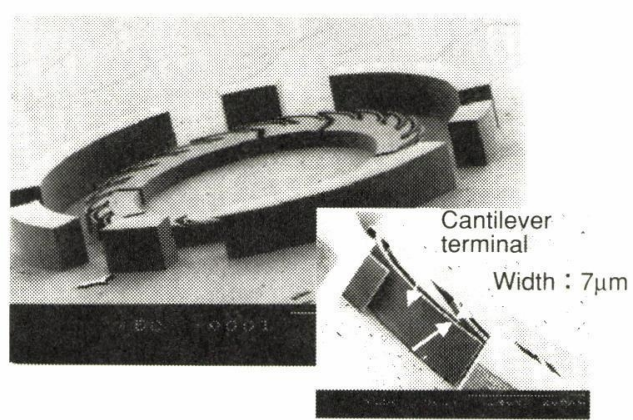

Fig.6 SEM micrographs of cantilever terminals (Female connector)

ことで支持部に支えられた片持ち梁はばねとして働くこと ができる。めっき金属としてはヤング率が高く内部応力の 発生の少ないことから電解Niめっきを採用した。われわ れの行った犠牲層プロセスは, “密着層”之“犠牲層”の 2 種類の層を有する一般的な犠牲層プロセス とは異なり, スパッタリングで製作したTi層 1 層に密着層と犠牲層の 両方の機能を持たせた。このようにすることで, 密着層や 犠牲層のパターンニングが不要となり, 製作プロセスの大 幅な簡素化を行うことができた。犠牲層プロセスを用いて 製作した片持ち梁構造の端子をFig. 6 に示す。アルミナ基 板上に製作した $2 \mu \mathrm{m}$ 厚のTi層上にLIGA-like Processを用 いて Ni構造体を製作し，ウエットエッチングにより一部 のTiを除去し，可動部を製作する。製作した片持ち梁の 寸法は, 幅 $7 \mu \mathrm{m}$, 高さ $80 \mu \mathrm{m}$, 長さ $300 \mu \mathrm{m}$ である。端子の ばね定数に大きく影響する端子幅の製作精度は土0.5 $\mu \mathrm{m}$ ある。次に，製作した方持ち梁の端子がばねとしての機械 的特性に大きく影響するめっき金属の結晶構造と密度分布 について述べる。

めっき金属の機械特性は結晶子の配向性や結晶子サイズ が大きく影響する ${ }^{9.10)}$ 。そのため, LIGA-like Processで製 作したNiめっき片持ち梁には，面方向だけでなく特にめ っき成長方向の配向性や結晶子サイズが均一であることが 要求される。めっき初期の配向性や結晶子サイズは一般的 に下地膜の影響を受けやすく, 成長方向に分布を持つこと がある。また, めっき条件や添加物によって配向性や結晶 子サイズは大きく変化する。すでにわれわれがLIGA Processの金型として用いていたNiめっき”は結晶粒サイズ が数 $100 \mathrm{~nm}$ と大きく，そのため弾性限界が約 $500 \mathrm{MPa}$ とば ね材としては低く脆いことに加え, Fig. 7 (a)に示すように 結晶粒の配向もめっき成長方向に分布していたため高アス ペクト構造のばね材として好ましくないことがわかった。

LIGA Processに適用可能なめっきとしては, 高アスぺ クト比のレジスト構造体間でも液の置換が可能なほどめっ き液の粘性が低く, かつ厚着けしてもマイクロクラックを 生じないめっきとしてNiやCuが一般的に用いられている。 しかしCuは硬度が低く, コネクション時のガイド同士の 衝突および摩擦で容易に変形または磨耗するため好ましく なかった。また, 近年MEMS用めっきとしてNi-Wが提案 されているが"1, 現時点ではめっき液管理が難しいため, 

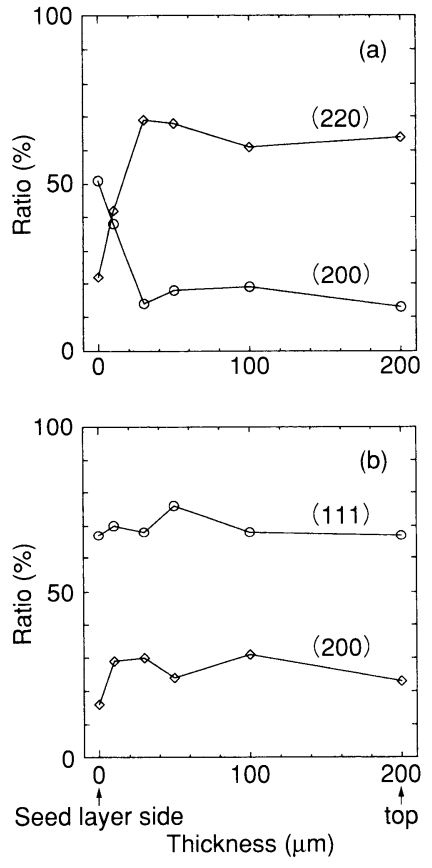

Fig.7 Variation of preferred orientation of the Ni grains

(a) Normal Ni electroforming for LIGA mold.

(b) Ni electroforming for cantilever terminal.

(Both the orientations were measured by XRD)

めっきごとの機械特性のばらつきが大きく，また，めっき の内部応力が大きいため端子可動部の反りが予想されたの で，今回は使用しなかった。そこで，われわれは今まで使 用してきたスルファミン酸Niめっき液にサッカリンやブ チンジオール等の添加剤を加えることによって, 結晶粒サ イズの小径化拉よびめっき成長方向に対する配向性拉よび 結晶子サイズの均質化を図り，ばね性の向上を試みた。 Fig. 7 (b)执よびFig. 8 にマイクロコネク夕端子製作に用い たNiめっきの配向性と結晶子サイズの厚さ方向分布を示 す。なお，配向性と結晶子サイズはX線回折測定により求 めた。測定結果からわかるように（111）配向性を持って おり，Wilson法にて求めた結晶子サイズは10～12nmであ

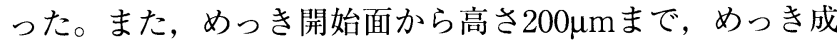
長方向に扔いて配向性，結晶子サイズともきわめて一定で あり，結晶構造的に均質であることが確認できた。さらに， （111）配向であることはヤング率が高くなる傾向であるこ

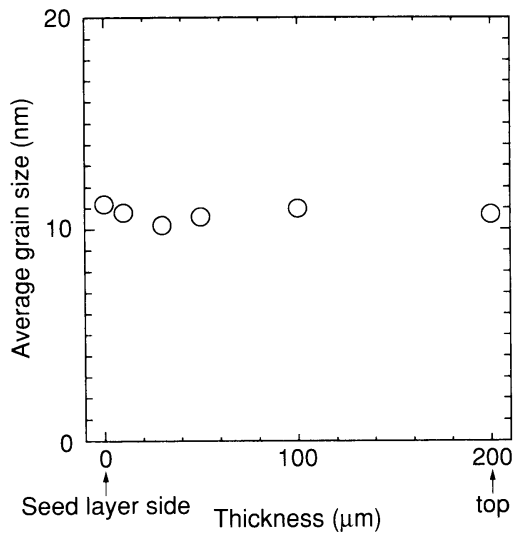

Fig.8 Average grain size variation of $\mathrm{Ni}$ fabricated using LIGA-like Process
とを示しており，また結晶子サイズが小さいことはHallPetchの関係から，硬く勒性の高い材料であることを示し ている。このことはLIGA-like Processで製作した模擬端 子のヤング率が250GPa（Ni圧延材：約200GPa）と高く, 弾性限界も $1000 \mathrm{MPa}$ 高い值を有していることとも一致 する ${ }^{3)}$ 。高いヤング率を有することで微細な端子でも十分 な接触圧を得ることが可能となり，また弾性限界もばね材 として十分であることから，本めっきは微細端子製作に適 していると言える。

次にLIGA-like Processで製作したNi構造体の密度分布 の測定結果について述べる。測定は大型放射光装置 “SPring-8”から得られる $12.0 \mathrm{keV}$ の高輝度単色X線を用い て測定した。測定サンプル形状は断面が 1 辺 $20 \mu \mathrm{m}$ の正方

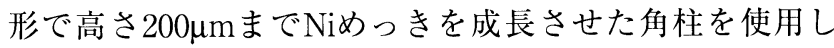
た。測定に使用したX線ビームのサイズは $0.5 \mu \mathrm{m} \times$ $1.8 \mu \mathrm{m}(\mathrm{FWHM})$ まで集光している。Fig. 9 に示すように, 密度ばらつきは測定サンプル全体で $6 \%$ 以内であり，均一 であることが確認できた ${ }^{12)}$

\section{2 ガイドの製作方法}

コネクタの端子のスムーズな接続やコネクタ間の位置ず れの補正を行うため，雄側のコネクタの端子およびガイド にはテーパ構造を設けている。端子扦入の際にこのテーパ 構造端子によって片持ち梁端子を挿入方向に対して垂直に 変位させながら挿入するため，テーパ部から加わる力によ って方持ち梁がしなりながらたわみ，複雑な応力が負荷さ れることになる。また，テーパ角が大きいと方持ち梁の挿 抜方向の変形量が大きくなり，端子可動部と基板の接触を 生じ端子の動きを妨げる可能性がある。こうした端子の詳 細挙動を評価するため 3 次元モデルでのFEM解析を行い テーパ角を決定した。解析結果をFig.10に示す。なお，端 子に生じる応力の最大值は繰り返し㨂抜にも耐えうる寿命 を考慮し，弾性限界の1/5の200MPa以下となるよう設計 を行った。端子挿入時に生じる応力が挿入後の最大応力と ほぼ等しくなるテーパ角は 15 度以下で，さらにこのときの 方持ち梁先端の抻抜方向の最大変形量も $0.88 \mu \mathrm{m}$ と犠牲層 厚さ $2 \mu \mathrm{m}$ に比べ十分小さかったことから，テーパ角を 15 度とした。

LIGA-like Processは垂直な側面を有する2.5次元構造を 高精度に製作するには最適であるが，垂直構造とテーパ構 造が混在するような複雑な 3 次元構造を製作することは難 しい。そこで, テーパ構造は, LIGA-like Processとマイ クロ放電加工（ $\mu$-EDM）を組み合わせることで実現した。

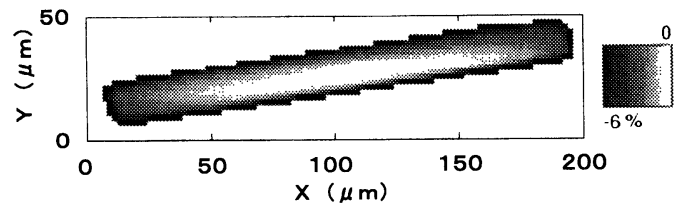

Fig.9 Measured density variation map of a electroformed rectangular prism of $\mathrm{Ni}(20 \mu \mathrm{m} \times 20 \mu \mathrm{m} \times 200 \mu \mathrm{m})$ 


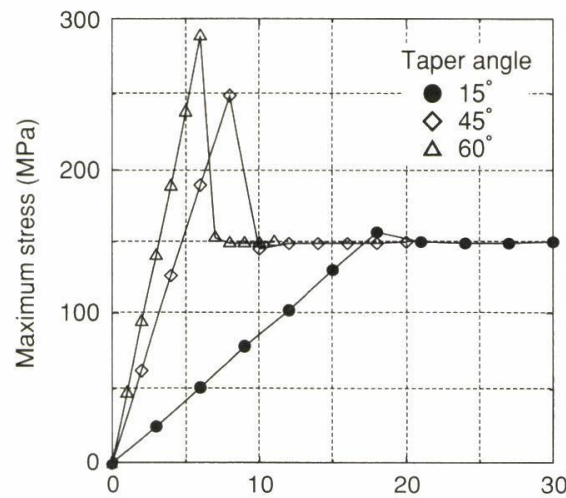

Insertion distance of tapered terminal $(\mu \mathrm{m})$

Fig.10 Taper angle dependence of bending stress of cantilever terminal (Results of FEM analysis)

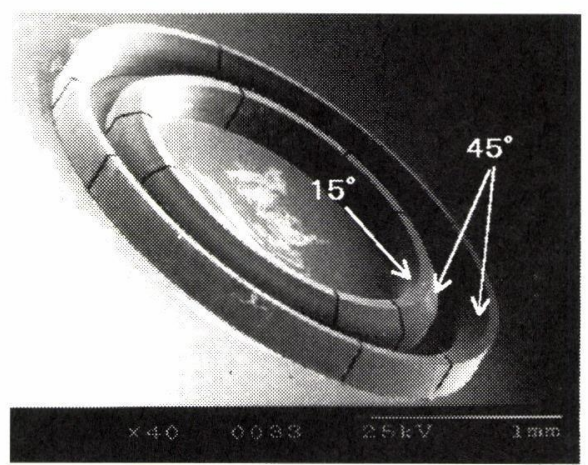

Fig.11 SEM micrographs of tapered guides and terminals (Male connector)

まず，垂直なNi構造体をLIGA-like Processを用いて製作 し，その構造体に対して放電加工で追加工した。製作した テーパ構造をFig.11に示す。放電加工面の表面荒さは $50 \mathrm{~nm}(\mathrm{Ra})$ 以下であり，加工精度も $\pm 1 \mu \mathrm{m}$ を達成する ことができた。また，放電加工時の熱による加工面の変質 は，放電加工条件を最適化することによって加工変質層厚 さを $1 \mu \mathrm{m}$ 以下にし，その影響を最小限に抑えだ”。マイク 口な 3 次元構造体を製作する手法としてLIGA-like Processと $\mu$-EDMの組み合わせはきわめて有効である。

\section{4. 微細端子表面への金コーティング}

低い端子間接触荷重でも安定した電気的な接続を得るた め, マイクロコネクタ端子への金コートを試みた。金コー ト方法としては，端子部のみをコートする必要からめっき によって行うこととした。これまで, LIGA構造体を電気 端子として使用した例は少なく，その表面に金等の表面コ 一トを施した例はほとんどない。マイクロコネクタの電気 端子のような高アスペクト比構造体への金コートでは高さ 方向の厚さの均一性が悪いことが予想され，またコネク夕 として十分な耐摺動磨耗性を持っているかが懸念された。 そこで，無電解めっきと電解めっきの比較を行った。

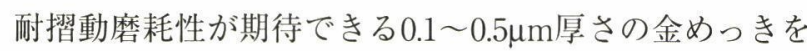
試みた。AFM測定による金被膜の表面荒さは $30 \mathrm{~nm}(\mathrm{Ra})$ 程度であり，めっき前の $\mathrm{Ni}$ 表面と同等の粗さであった。

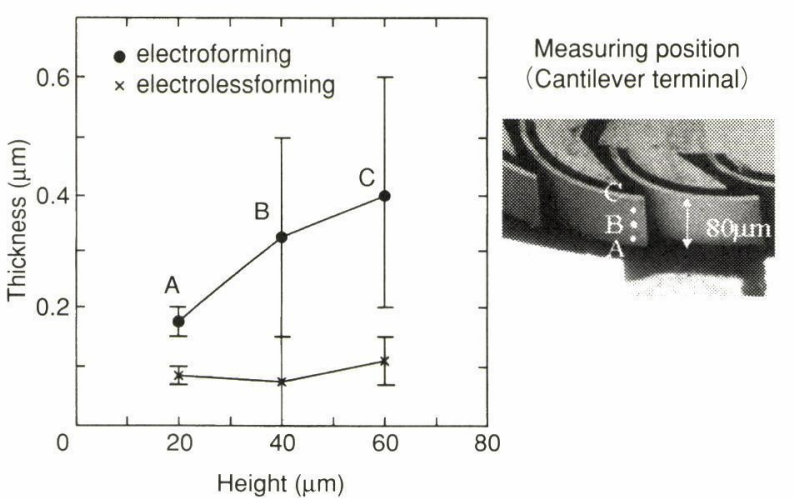

Fig.12 Uniformity of the Au layer

金被膜の厚さの均一性をFig.12に示す。電解めっきでは, 端子の基板側とで極端に厚さに差が出た。この原因は, 高 アスペクト比端子を高密度で配置したことによる高さ方向 の電界分布の影響と思われる。これに対し無電解めっきで は，端子表面の洗浄不良により金めっきが形成されていな い個所が若干見られたが，厚さが比較的均一であり必要な 金めっき厚さも得ることができた。均一性や寸法精度とい う観点からは無電解めっきのほうが良く, 高アスペクト微 細構造体への表面コーティングめっきとしては無電解の方 が好ましいことがわかる。なお，耐摺動性の測定結果につ いては次章で述べる。

\section{5. マイクロコネクタの電気的特性評価}

製作した雄・雌のマイクロコネクタ間の端子導通を得る ことに成功した。FPCを介した端子間の接続抵抗は $3.6 \Omega$ 線以下であり, FPCを除いた端子部のみの接続抵抗は $1.2 \Omega$ /線以下であった（Fig.13）。測定は四端子法で行っ た。マイクロコネクタの周波数特性はネットワークアナラ イザ（HP 8753D）を使用し測定した。伝送損失はDC〜 $130 \mathrm{MHz}$ まで $2.5 \mathrm{~dB}$ 程度でフラットであり，検査マシンに 搭載する周波数 $1 \mathrm{MHz}$ の探傷デバイスの信号を十分伝送 可能なことを確認できた（Fig.14）。

犠牲層プロセスのTiのウエットエッチングによりセラ ミックス基板の絶縁劣化が懸念されたため, 端子間の絶縁

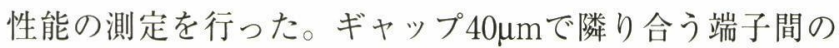

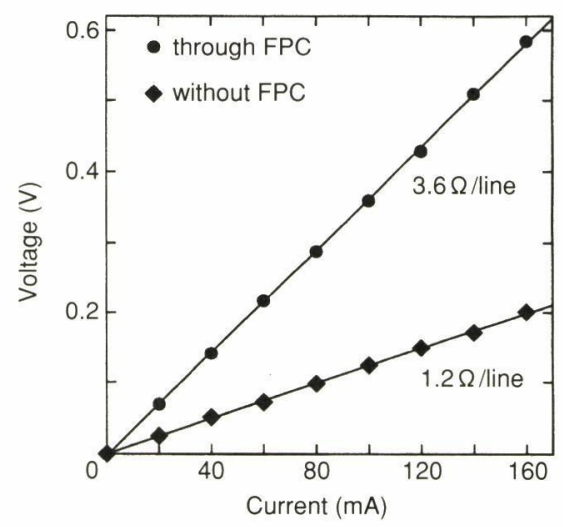

Fig.13 V-I characteristic of the microconnector 


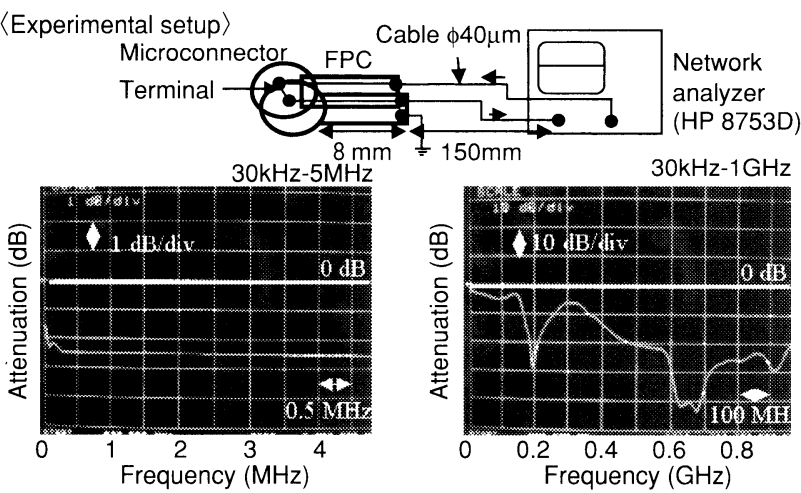

Fig.14 Attenuation characteristics of microconnector

絶縁抵抗は電圧 $250 \mathrm{~V}$ （DC）以下において $2000 \mathrm{M} \Omega$ 以上で あり，大気中での絶縁破壞電圧は370Vであった。これは マイクロマシンに搭載するデバイス（アクチュエータ，七 ンサ，モー夕等）を駆動するに十分な電圧である。

端子の金コートの耐摺動性について，マイクロコネクタ を繰り返し挿抜して調べた結果, 100回程度の繰り返し挿 抜では各層抜ごとの接続抵抗の変動は $\pm 0.4 \Omega$ 以内で，接続 抵抗の増大の傾向は見られなかった。さらに，試験後のコ ネク夕端子表面をSEMにて観察したところ金コートのは がれや端子の変形は観察されなかった。

マイクロコネクタの自動着脱機能試験は，まずあらかじ めコネクタの対向角や軸の調整を行った状態で行った。電 磁アクチュエータを励磁し（122AT，0.1秒），端子間ギャ

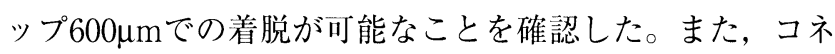
クタ間の角度ずれの補正可能な角度は，ギャップ $500 \mu \mathrm{m} に$

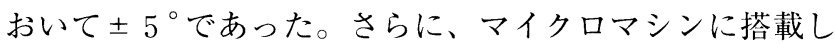
マシン同士の連結分離が可能なことを確認した”。

\section{6. 結 言}

DXL技術とめっき技術を組み合わせたLIGA-like Process を用いマイクロコネクタを製作した。LIGA-like Process によりきわめて微細な端子構造を高精度に製作することが 可能である。微細端子製作のためにわれわれが開発した Niめっきは，ヤング率抢よび弾性限界とも高くばね性に 優れ， $\mathrm{Ni}$ の密度分布も構造体全体にわたって均一である ことを確認できた。また，LIGA-like Processと犠牲層プ ロセス， $\mu$-EDMを組み合わせることで，片持ち梁構造や テーパ構造を製作することができる。金コートした微細端 子間の導通特性や絶縁性を測定し，マイクロマシンのデバ イスを駆動するに十分な性能を有したコネクタであること を確認した。LIGA-like Processを用いることでばね性を 有する微細な金属端子構造を高精度で製作できることか ら，マイクロコネクタだけでなく高集積化が求められてい る実装や検査の分野において様々な箇所へ適用できる技術 と考えられる。

\section{謝 辞}

本研究開発は工技院産技プロジェクトの一環として, NEDOから委託を受けたマイクロマシンセンターの再委託 業務として実施したものである。

(2000.8.30-受理２000.12.4-再受理）

\section{文献}

1) H.Narumiya : "Experimental Chain-Type Micromachine Inspection on Outer Surface of Tubes". The $3^{\text {rd }}$ Int. Micromachine Symp., Tokyo, p.141, 1997

2) M.Takeda, K.Namura, K.Nakamura, N.Shibaike, T.Haga and H.Takada: "Development of Chain-Type Micromachine for Inspection of Outer Tube Surfaces (Basic Performance of the $1^{\text {st }}$ Prototype)", $13^{\text {th }}$ IEEE Int. Conf. on MEMS, Japan, p.805, 2000

3) H.Okuyama, T.Haga, K.Emura and H.Takada : "Development of Microconnector with Automatic Connecting/Disconnecting Mechanism”, $12^{\text {th }}$ IEEE Int. Conf. on MEMS, USA, p.257, 1999

4) T.Haga, H.Okuyama and H.Takada : "Development of microconnector with an Automatic Connecting/Disconnecting Mechanism", Microsystem Technologies, Vol.6. No.4, p.157, April, 2000

5) 羽賀 剛, 奥山 浩, 平田嘉裕, 高田博史：“ディープ X線 リソグラフィーを基本とする 3 次元微細加工を用いたマイ クロコネクタの開発”, 電学論 $\mathrm{E}$, Vol.120, No.7, p.363, July, 2000

6) たとえば，真野国夫：“接触部品の信頼性”，電子総合出版， 1976

7) H.Takada, Y.Hirata, H.Okuyama and T.Numazawa : "Development of LIGA Process Using a Superconducting Compact synchrotron Light Source", Electrical Engineering in Japan, Vol.120, No.1, p.40, 1997

8) P.Bley and J.Mohe: "The LIGA Process", FED J., Vol.5 Suppl., 1, 1994

9) G.Carneval and J.B.de Cusminsky: "The Influence of the Anion on Copper Electrocrystallization", J.Electrochem. Soc., Vol.128, p.1215, 1981

10) たとえば，電気鍍金研究会編：“如き教本”, 日刊工業新 聞社， 1986

11) 池田英広, 井奥 淳, 藤田孝之, 前中一介, 前田宗雄 : “MEMS材料としての Ni-W 合金めっき膜”, 電学論 $\mathrm{E}$, Vol.119, No.11, p.598, 1999

12) K.Haga and H.Okuyama : "Caracterization of LIGA-Based Microstructures Using an X-ray Microprobe", SPring-8 User Experiment Report, 2000A, No.5, p.379, 2000 